\title{
THE UPPER SILURIAN CYATHASPID ARCHEGONASPIS FROM THE EAST BALTIC
}

Archegonaspis is one of the oldest representatives of the family Cyathaspididae (Heterostraci). The occurrences of this cyathaspid are not very frequent. It has been found in Gotland, England, Germany and Poland (in the latter two areas in erratics); a more recent find comes from Vaigach Island (see Denison, 1964; Новицкая, 1970). Most of the Archegonaspis finds are known from the Lower or Middle Ludlovian rocks, with the exception of a specimen reported from the Early Devonian of England (see White, 1958). The taxonomic position of this specimen, as well as Archegonaspis ludensis (Salter)
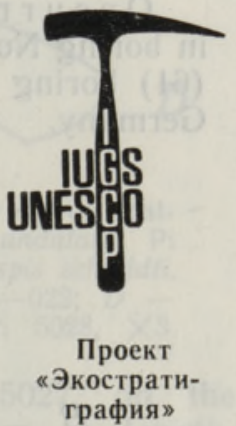
from the Ludlovian of the same region is, however, not firmly established.

In the present paper, the Archegonaspis remains from the Ludlovian and lowermost Downtonian of the East Baltic area (Estonia, Latvia and Kaliningrad Region) are described for the first time. The remains come from bore-cores. They are represented by some specimens of the anterior portion of dorsal shield and several small fragments.

The specimens with indexes $\mathrm{Pi}$ are housed at the Geological Museum of the Estonian Academy of Sciences.

I am much indebted to colleague V. Karatajute-Talimaa, Lithuanian Institute of Geology, Vilnius, for the specimen of Archegonaspis (coll. No. 25-022) from Kaliningrad Region.

\section{Description}

\section{Archegonaspis Jaekel, 1927}

Type-species. Cyathaspis (Pteraspis) integer Kunth, 1872.

$\mathrm{D} i \mathrm{a} g \mathrm{nos}$ is. The dorsal shield is elliptical. The maximum length of the dorsal shield is $38-47 \mathrm{~mm}$, width ratio $0.59-0.64$, orbital ratio $0.15-0.19$, pineal ratio $0.22-0.31$, postbranchial ratio 0.27 . There is no median rostral process; preorbital processes are well developed, postbranchial lobes are weak. The posterior edge of the shield is nearly transverse, sometimes with a small postero-median process. Epitega and postrostral field are distinct. There may be a primordial area on the central epitegum. The ridge pattern is transverse on the rostral, elliptical on the central epitegum, and longitudinal on the lateral epitega. There are $4-6$ dentine ridges per $\mathrm{mm}$. On the ventral shield the pattern 
is longitudinal, with an anterior area of fanned ridges. (Abridged after Новицкая, 1970.)

O c curren ce. Late Silurian, Ludlovian of North Germany, Poland, Gotiand, England (?), Latvia, Kaliningrad Region and Vaigach Island. In the Estonian Silurian section, Archegonaspis has been found in the Paadla Sitage, Ludlow, and at the base of the Kuressaare Stage (lowermost Downtonian).

\section{Archegonaspis schmidti (Geinitz), 1884}

T y p e. Dorsal shield, 38 mm long; Rostock University Museum; glacial erratic of the Graptolithengestein, Early Ludlovian.

Diagnosis. The ornamentation consists of dentine ridges which are of uniform size and moderately convex. They continue almost without interruption on the whole length of the rostral epitegum.

Occurrence. Upper Silurian, Lower Ludlovian, Birštonas Beds in boring No. 1 (depth $1535 \mathrm{~m}$ ), Kaliningrad Region; Ludlovian in Edole (61) boring (depth $597.3 \mathrm{~m}$ ), Latvia; Lower Ludlovian erratics of North Germany.

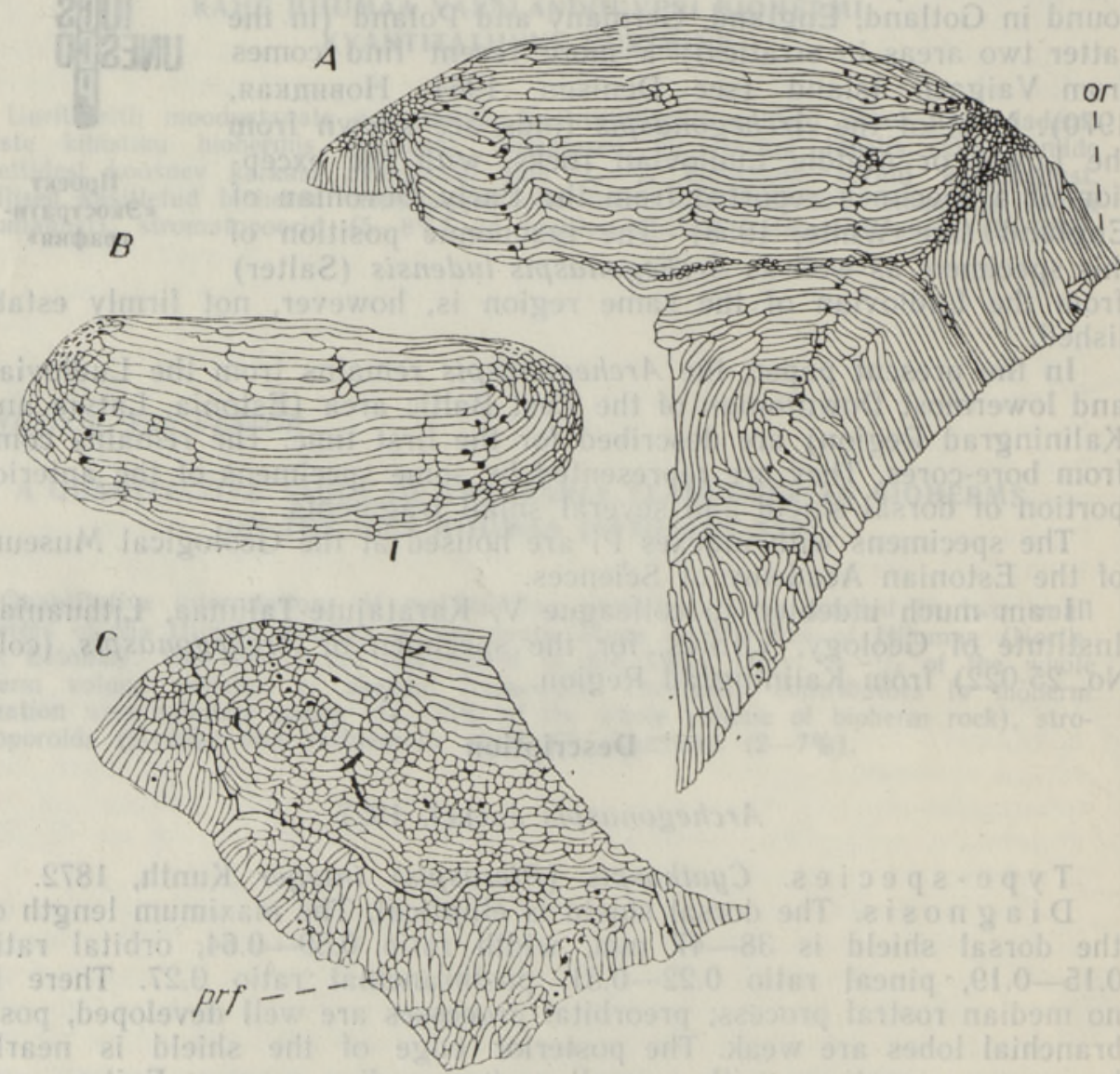

Fig. 1, A, B - Archegonaspis schmidti; $C-$ Archegonaspis sp. A, pattern of dentine ridges on anterior part of dorsal shield. $A-\mathrm{Pi} 5027 ; B-25-022$; $C-\mathrm{Pi} 5028, \times 4^{1 / 2}$. or - orbit; prf - postrostral field. 
Description. The specimens $\mathrm{Pi} 5027$ and 25-022 (Fig. $1, A, B$; Plate, Figs 1, 2) are the anterior portions of dorsal shield. These shields are arched dorsally (Fig. 2, B, C). Their anterior borders are smoothly convex. The rostral borders are folded, forming the maxillary brim (Plate, Fig. 5). The length of this brim in $\mathrm{Pi} 5027$ is $1.7 \mathrm{~mm}$, breadth $11 \mathrm{~mm}$. Median rostral process is absent (Fig. 2, B, $C)$, preorbital processes are relatively well developed. Orbital length in $\mathrm{Pi} 5027$ is $5 \mathrm{~mm}$, orbital width $19 \mathrm{~mm}$. The thickness of the shield is $0.6 \mathrm{~mm}$. The dorsal shield in A. schmidti is divided into distinct epitega by sutures and ridge pattern (Fig. 1, $A$ ). The postrostral field is not clearly developed. There are grooves with denticulate ridges between the epitega. In $\mathrm{Pi} 5027$, on the right side, this groove changes into a ridge of $2 \mathrm{~mm}$ in length. The surface of the shield is covered with round-crested dentine ridges of uniform size. The maxillary brim is covered with 8 transverse dentine ridges anteriorly and denticles posteriorly (Plate, Fig. 5). There is a band of ridges parallel to the limits of the epitega on the central epitegum (Fig. 1, $A$ ); some ridges run from the pineal region anteriorly and laterally (4.5 per mm). On the lateral epitegum the ridges (6 per mm) curve over the orbital notch and converge with transverse rostral ridges anteriorly on the preorbital process. Here the ridges are denticulate. Posteriorly they run parallelly to the ridges of the lateral part of central epitegum.

The sensory line canals terminate with pores. The pores of the supraorbital canal and a single pore of the medial dorsal canal are visible (Fig. 3, $A, B$ ).

\section{Archegonaspis sp. A}

Pi 5028 (Fig. 1, C; Plate, Fig. 3) is the anterior part of dorsal shield of a cyathaspid from the Upper Silurian (Ludlovian), Edole (61) boring (depth $594.1 \mathrm{~m}$ ), Latvia. Its anterior border is almost straight. The rostral border is folded downwards, forming the maxillary brim (Plate, Fig. 6) that is shorter than in Archegonaspis schmidti (Plate, Fig. 5). Median rostral process is absent in both forms (Fig. 2, $B-D$ ). The rostra of Archegonaspis species can be compared with the rostrum of Tolypelepis undulata Pander (Fig. 2, A; Plate, Fig. 4). It also lacks a median rostral process, but the maxillary brim is not developed, the anterior margin being somewhat thickened. Orbital length of Archegonaspis sp. A is $4 \mathrm{~mm}$, orbital width $17 \mathrm{~mm}$. The thickness of the shield is greater than in $A$. schmidti, being $0.7-0.8 \mathrm{~mm}$. The epitega are not 


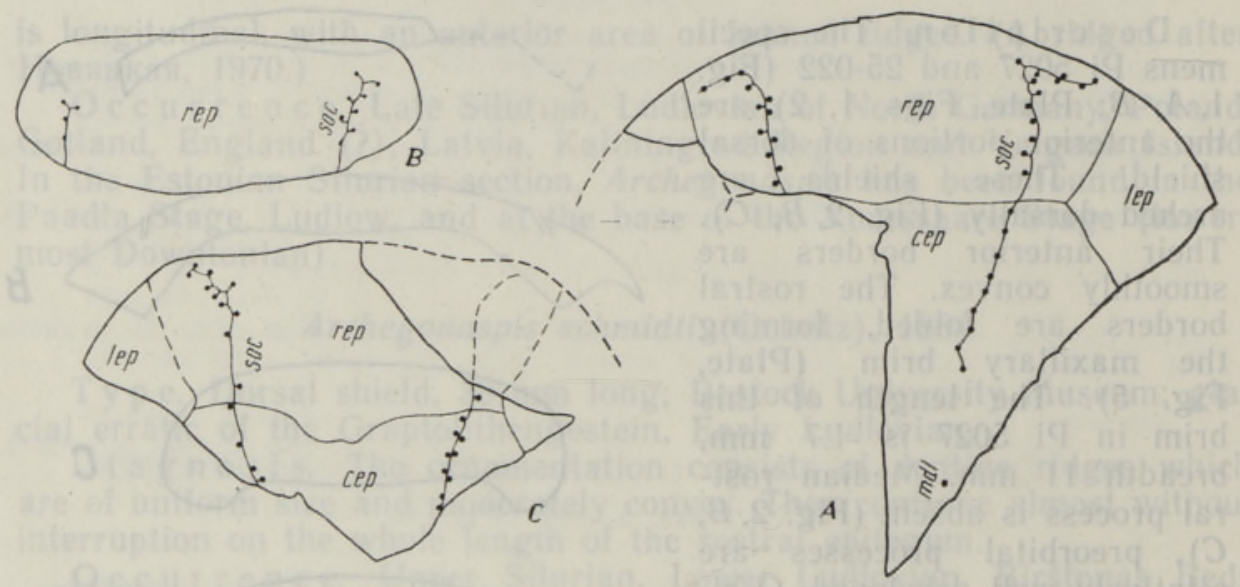

Fig. 3, A, B - Archegonaspis schmidti, $C-$ Archegonaspis sp. A, canals of lateral line system and epitega of dorsal shield. $A-\mathrm{Pi} 5027 ; B-25-022 ; C-$ Pi $5028, \times 3$.

cep - central epitegum; lep - lateral epitegum; $m d l$ - pore of medial dorsal sensory canal; rep - rostral epitegum; soc - pores of supraorbital canal; continuous line shows the supposed course of supraorbital canals.

so clearly developed as in $\mathrm{Pi}$ 5027. The postrostral field (Fig. 1, C) is distinct. The ridges of the postrostral field radiate fan-wise from the pineal region. The dentine ridges differ from those in $A$. schmidti in being divided into short lengths. The specimen is coarser-ridged (4 per $\mathrm{mm}$ on the rostrum) than $A$. schmidti (5 per mm on the rostrum). The laterally curved pores of supraorbital canal (Fig. 3,C) are placed similarly to those in a specimen of $A$. schmidti.

\section{Archegonaspis sp. B}

There are some fragments of Archegonaspis found in the Paadla Stage, Uduvere Beds and in the Kuressaare Stage, Tahula Beds of Estonia (in Kingissepa and Ohesaare borings at the depth of $3.60-$ 18.10 and $93.21-98.80 \mathrm{~m}$, respectively). The ornamentation of these fragments consists of dentine ridges of uniform size, with flat or rounded crests. The coarseness of ridges is very variable. Commonly there are $4-6$ ridges per $\mathrm{mm}$, but there also occur 9 ridges per $\mathrm{mm}$.

\section{REFERENCES}

Denison, R. H. 1964. The Cyathaspididae. A family of Silurian and Devonian jawless vertebrates. Fieldiana: Geol,, 13, No. 5.

White, E. J. 1958. Original Environment of the Craniates. In: Studies on Fossil Vertebrates. London.

Но в и ц кая Л. И. 1970. Позднесилурийский Archegonaspis на острове Вайгач. Палеонт. ж., № 3.

Academy of Sciences of the Estonian SSR, Institute of Geology

Received

Febr. 17, 1976 


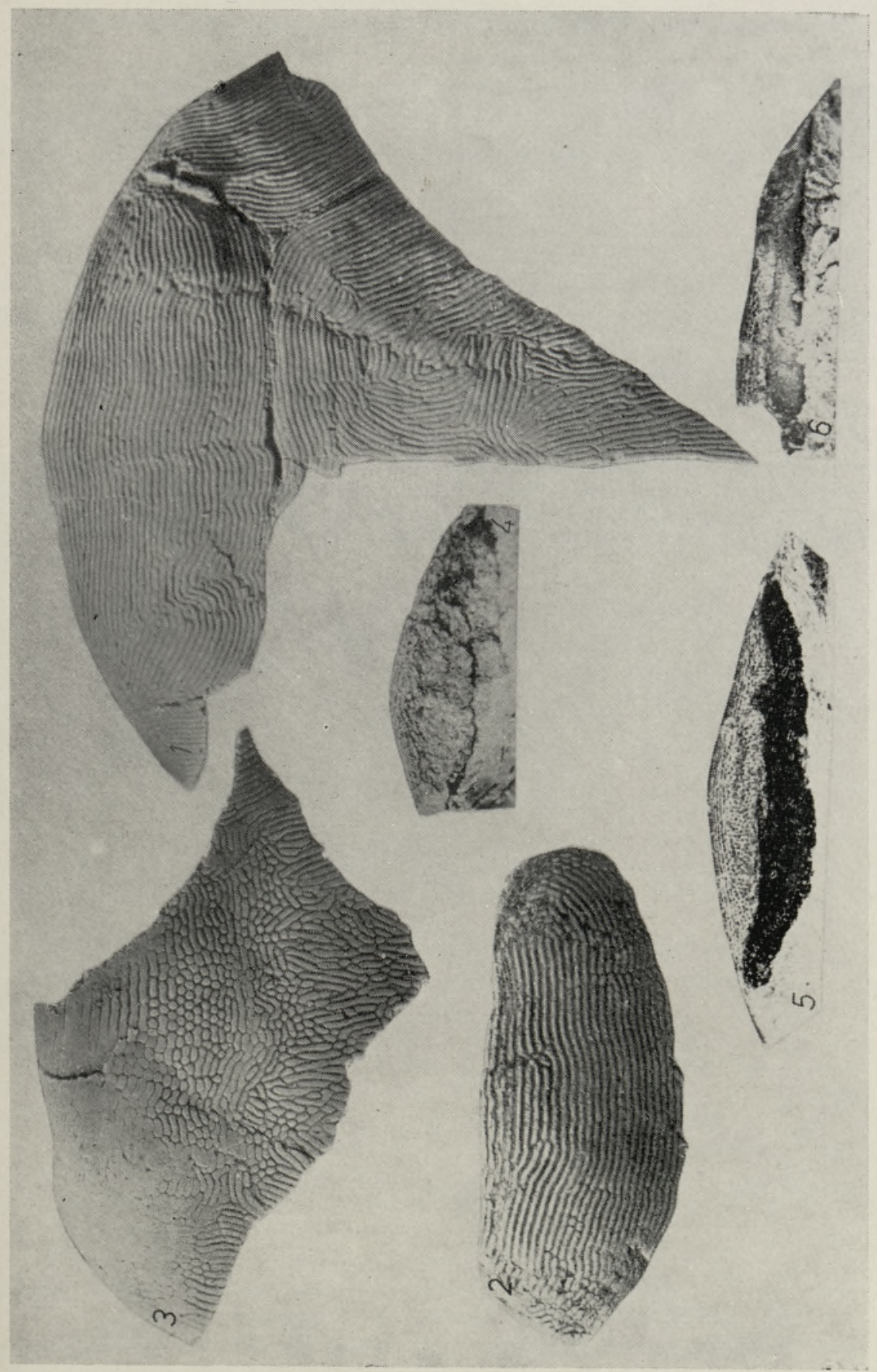

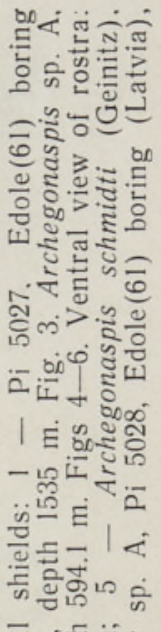

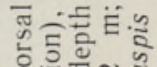

은ㄷำ

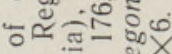

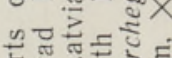

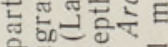

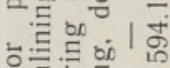

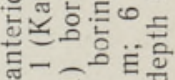

. $\bar{\Xi} \approx$

글 on 을

든엉혀

이에요

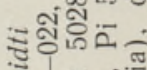

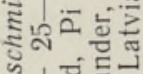

证矛

ผ N

ถึ่

का के

งั่ํํำ

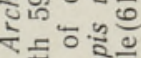

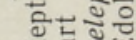

ง 范围

- ํํำำ

on

诖嵒芘 

Tiï MÄRSS

\section{OLEMSILURI TSUATASPIID ARCHEGONASPIS IDA-BALTIKUMIS}

Artiklis kirjeldatakse tsüataspiidide Archegonaspis schmidti ja Archegonaspis sp. A dorsaalkilbi eesmist osa. Archegonaspis'e leiud Ida-Baltikumi silurist on esmakordsed. Nende hulka kuuluvad ka väikesed fragmendid, mis pärinevad Eestist paadla lademe uduvere kihtidest ja kuressaare lademe tahula kihtidest (Archegonaspis sp. B).

\section{Tuйy МЯРСС}

\section{ЦИАТАСПИД ARCHEGONASPIS ИЗ ВЕРХНЕГО СИЛУРА ВОСТОЧНОЙ ПРИБАЛТИКИ}

Описываются передние части дорсальных щитов Archegonaspis schmidti и Archegonaspis sp. А из Латвии и Калининградской области. Эти остатки Archegonaspis, как и фрагменты из удувереских слоев паадлаского горизонта и тахуласких слоев курессаареского горизонта Эстонии (Archegonaspis sp. В), обнаружены в Восточной Прибалтике впервые. 